\title{
Policy instruments and barriers to rural tourism development - a case study of cluster in the Liptov touristic region in Slovakia
}

\author{
Katarína Melichová, Lubica Majstríková, Maroš Valach and Michal Strnál
}

\begin{abstract}
Department of Public Administration, Faculty of European Studies and Regional Development, Slovak University of Agriculture in
\end{abstract} Nitra, Trieda Andreja Hlinku 2, 94976 Nitra, Slovakia

E-mail address: katarina.melichova@uniag.sk

\begin{abstract}
Tourism industry, in general, and rural tourism specifically is often promoted as a go-to solution to the various problems that rural regions and communities are currently facing. In Slovakia, several policies have been formulated and implemented in order to harness this potential in reality. The main aim of this contribution is to (via an in-depth case study of a tourism cluster in Liptov region in Slovakia) find out the current state of the policy instruments being implemented to promote the development of rural tourism as well as barriers that hinder the effectiveness of said instruments. By means of questionnaire survey and interviews with relevant stakeholders (accommodation providers, representatives of local self-government and support organizations at the local and regional level) we identified both financial and institutional hurdles, but also a difference in opinions of different actors concerned.
\end{abstract}

Keywords - Rural tourism, cluster, policy instruments, development barriers.

Received: October 28, 2018

Accepted: December 31, 2018

\section{Introduction}

According to the Tourism Development Strategy of the Slovak Republic up to 2020 (Ministry of Transport and Construction, 2013), "tourism is an economic activity that in the EU is capable to generate growth and employment and contributes to economic and social development and integration, especially in rural and mountain areas, coastal regions and islands, peripheral and very remote regions. ". The tourism sector in Europe includes around 1.8 million mainly small and mediumsized enterprises employing around 5.2\% of the total workforce. The Government of the Slovak Republic set an objective for the period up to 2020 , to create conditions in rural regions for comprehensive support of rural tourism and agro-tourism development, including building infrastructure, missing institutions, information and reservation system and promotion of marketing in tourism. The emergence of rural tourism, as one of the tourism forms, according to UNWTO (2007), was mainly influenced by the industrialization and urbanization that caused a need of urban population to compensate the lack of recreational space. Another factor influencing the development of rural tourism was the growth of population mobility (Vaisová, 2008). According to Macha (1993), changes in market economy principles and the search for new opportunities for the valuation of agricultural products also affected the development of rural tourism.

Galvasová (2008a) defines basic factors influencing the development of tourism (rural tourism) as natural, cultural-historical and socio-economic factors. Within socio-economic factors, she includes demographic, urbanization, economic, socio-cultural and socio-political conditions. Natural factors such as relief, climatic conditions, water, flora, and fauna are considered to be the decisive localizing factors of rural tourism (Toušek, Kunc, Vystoupil, 2008). Cultural-historical factors include cultural-historical monuments, cultural facilities and cultural programs (Michalík, Lenovský et al., 2014). According to Medvecká (2006), this category encompasses, in particular, the cultural heritage and collection fund of museums and galleries, as well as various cultural facilities and live cultural events, whether professional artistic productions or folk culture. Traditional meals can be counted as one of the heritage features (Bessiére, 2008) as well as traditional architecture (Kurpaš and Zima, 2012). Other factors that support the development of rural tourism were characterized by Irshad (2010); including accessibility, in terms of removing economic and political barriers and 
infrastructure development that has improved the accessibility of rural areas.

Instruments in the context of development can be defined as all means that help to achieve development goals of the territory. Binek et al. (2009) define two main groups of development tools: financial and non-financial. Based on the definition of rural development tools and tourism development tools given by several authors (Wokoun and Mates, 2006; Binek et al., 2009; Hudec, 2009; Jarábková, 2010; Maier and Tödtling, 1998) we can conceptualize the basic structure of rural tourism support tools as follows (Tab.1):

Table 1 Division of support instruments for rural tourism development

\begin{tabular}{|c|l|}
\hline \multicolumn{2}{|c|}{ Support tools for rural tourism development } \\
\hline \multirow{3}{*}{$\begin{array}{c}\text { Financial } \\
\text { tools }\end{array}$} & Investment and non-investment incentives \\
\cline { 2 - 2 } & Tax benefits \\
\cline { 2 - 2 } & Other financial tools \\
\hline \multirow{4}{*}{$\begin{array}{l}\text { Non- } \\
\text { financial } \\
\text { tools }\end{array}$} & Administrative tools \\
\cline { 2 - 2 } & Programming tools \\
\cline { 2 - 2 } & Institutional tools \\
\cline { 2 - 2 } & Infrastructure tools \\
\cline { 2 - 2 } & Information tools \\
\hline
\end{tabular}

Source: own elaboration based on Wokoun and Mates, 2006; Binek et al., 2009; Hudec, 2009; Jarábková, 2007; Maier and Tödtling, 1998)

Financial tools that can support the development of rural tourism are implemented by various entities. One of the most important financial tools used mainly by tourism enterprises, but also by municipalities and the non-profit sector is the financial support through subsidies. Financial subsidies are drawn not only from European Union funds (e.g. European Social Fund, European Agricultural Fund for Rural Development, European Regional Development Fund) but also through financial mechanisms from other countries (Norwegian and Swiss financial mechanism), national budget, and regional selfgovernment budget. An example is the Nitra Selfgoverning Region, which in the framework of sustainability of the project "Certification of Accommodation Facilities in the Countryside" has earmarked $€ 12,000$ from the budget for the year 2016, supporting mainly marketing activities of specific accommodation facilities (Nitra Self-governing Region, 2016). Collection of tax on accommodation that is paid by visitors for accommodation services through operators of these facilities is also a very often used allocation tool for certain financial resources (at the local level). The government may also use various tax concessions for operators of accommodation facilities, such as in Poland, where farmers do not have to pay income tax from their diversified activities towards agro-tourism if they provide accommodation with a bed capacity of fewer than 10 beds. However, in Slovakia, this form of tax concession does not work.
Many non-financial tools are used to support the development of rural tourism, including a wide range of tools such as administrative, programming/conceptual, legislative, institutional, infrastructure or information tools. Administrative tools are various bans, orders, limitations and rules, such as standards (Výrostová, 2010). Examples of standards can include the ones formulated by the organization Eurogites that has set up rules for member organizations regarding equipment of accommodation facilities, services provided, and security measures. The aim of these standards is unification and transparency of services on the international market. In almost every country we find an example of introducing some form of standards; the overall goal is through comparing individual facilities to improve their quality by introducing various support activities such as education in the area of services, product development or business economics.

Programming/conceptual tools include the design of strategic, conceptual and programming documents. At the national level, these include mainly Tourism Development Strategy up to 2020, Regionalization of Tourism in the Slovak Republic, Marketing Strategy of the Slovak Tourism Agency 2014-2020, but also the Rural Development Program 2014-2020 (Gúčik, 2010, rev. 2017). At the regional level, these tools are represented, in particular, by programs of economic and social development, as well as tourism marketing strategies, which are mostly prepared by regional tourism organizations. The development program of the municipality, the marketing strategy of municipal development and the tourism development strategy are the most common documents created at the local level, comprising strategic planning including setting targets and tools for rural tourism development. Binek et al. (2007) also add to these documents the land-use and landscaping planning documents. However, all of the above-mentioned documents require the involvement of stakeholder groups so that individual measures are specific enough and, in more importantly, achievable. Other important tools for supporting rural tourism are legislative instruments, for example, laws, decrees or generally binding regulations. In the case of the Slovak Republic, Act No. 91/2010 Coll. on promoting tourism is important; it has set the conditions for institutionalization and cooperation of actors at the local and regional level. The law also addresses the issue of funding entities at the regional level.

In the institutional tools applied in Slovakia, we can also include the creation of regional and territorial tourism organizations, bringing together different entities (local self-government, business entities, and interest associations) and ensuring their coordination. In other countries, various support organizations are established that provide connection of tourism entities with research organizations, consulting for entrepreneurs, and ensure joint marketing of the tourist destination (Gúčik, 2012). Following the definition of institutional tools and the need for an integrated approach, it is important to define the concept of cooperation between tourism entities. This 
concept is associated by several authors (Jamal and Getz, 1995; Himmelman, 1996; Kučerová, 1999; Wang and Krakover, 2008; Michálková, 2010) with concepts such as networking, coordination or partnership. Collaboration at the destination of tourism represents the interaction of legally and economically independent entities involved in product development and tourism development in order to achieve common goals and synergy effect (Maráková, Gajdošík, 2013).

Tourism entities are motivated to cooperate with other entities in different ways (such as simplifying the introduction of innovation, improving marketing, obtaining financial support, exchanging information, consulting, education, sharing administrative costs, restoring cultural and historical heritage, developing strategies and concepts of tourism development, etc.). Cooperation in the development of tourism is manifested in various ways and forms of cooperation. Palenčíková (2010) argues that the content of the cooperation of tourism entities in the public and private sector is diverse and depends on the structure of the tourism product and relevant stakeholders. Infrastructure support tools (as described in Jovanović and Ilić, 2016) for rural tourism include the construction and reconstruction of technical and civil infrastructure (road network, waste management, connection to water, gas, electricity and the operation of civic amenities). Information tools include areas such as education, consulting, communication and marketing. These are mostly low-cost tools that are used at all management levels and by all entities involved in the development of the relevant sector. As García et al. (2012) point out, another example may be the creation of a specific brand characteristic for the territory/destination of tourism (e.g. the Region of Liptov) or form of tourism (e.g. Nitra self-governing region - certified rural accommodation).

The problem of setting up rural tourism support tools is the use of a top-down approach (Plzáková, Studnička, 2013), while most of these tools are applied at lower levels of management. It should be pointed out, that it is problematic to set up tools that could be widely used, because the territories, their management, but also the entities operating in these territories are often diametrically different. At the same time, individual tools should complement each other in order to achieve set objectives. Galvasová et al. (2008b) add that the creators of individual tools should distinguish between internal and external ways of fostering development, taking into account what can be applied by development actors in the given region themselves and what should be applied from the external environment. Other barrier that may negatively affect the ability to use the potential of tourism (at different levels), is the insufficient level of different forms of tourism support. In addition to the already mentioned barriers, passivity and unwillingness to cooperate, whether on the part of general public or entrepreneurs plays a role and it is often cause by lack of information (Paimin et al., 2014). Petrychenko and Melnyk (2013) also add the political and economic instability of the country, a factor which is not very significant in Slovakia.

The aim of the paper is to identify attitudes and needs of the entities of the rural tourism industry in connection to selected support mechanisms as well as to identify barriers to the development of tourism industry from the point of view of different stakeholders.

\section{Materials and methods}

The research methodology is based on the application of a questionnaire survey and a semi-structured interview with relevant stakeholders. In the framework of evaluation of the obtained primary data, we have focused on the analysis of contrast in responses of various stakeholder groups. Such approach generates relevant results in the context of potential application in practice in an effort to reconcile the attitudes of individual stakeholders.

As part of the research in the selected region (the Tourism region of Liptov), we have administered the questionnaire to the 31 entities from public, private and non-profit sectors that are involved in the development of rural tourism. We redistributed them into three groups: municipalities, accommodation and catering facilites and tourism support organizations. We have focused on municipalities located within the Žilina self-governing region in districts Liptovský Mikuláš and Ružomberok (total of 10 municipalities: Bešeňová, Dúbrava, Galovany, Gôtovany, Ivachnová, Liptovská Štiavnica, Liptovské Sliače, Liptovský Trnovec, Partizánska L’upča, and Štiavnička). Accommodation and catering companies were represented by business entities whose main economic activity is the operation of tourist and other short-term accommodation and accommodation in hostels and other temporary accommodation. Other respondents were the representatives of Žilina Self-governing Region, the Regional Tourism Organization "Žilina Tourist Region", the Local Action Group "Stredný Liptov", the Civic Association InfoLiptov and the Tourism Civic Association of Liptovský Trnovec. Representatives of municipalities have evaluated the tools that the municipality uses to support rural tourism and the importance of individual tools. Operators and support organizations (such as civic associations, regional tourism organizations) have evaluated the tools used by municipality in which territory they are located as well as the importance (on a scale of 1 to 5) of these individual tools depending on how they influence or would influence their business in rural tourism or the overall development of rural tourism.

The size of the research sample was determined on the basis of information saturation; i.e. we stopped addressing other respondents when the answers started to repeat.

\section{Results}

Table 2 provides a mirror image of the use and perception of tools used to support rural tourism and points to the 
Table 2 The share of entities who have expressed their positive opinion on the existence and use of defined support tools

\begin{tabular}{|l|l|l|l|l|}
\hline Support tools & \multicolumn{1}{|c|}{$\begin{array}{c}\text { Local self- } \\
\text { government }\end{array}$} & $\begin{array}{c}\text { Accommodatio } \\
\text { n providers }\end{array}$ & $\begin{array}{c}\text { Support } \\
\text { organizations }\end{array}$ & All entities \\
\hline Strategic document creation and planning & $90.00 \%$ & $66.67 \%$ & $66.67 \%$ & $74.19 \%$ \\
\hline Providing consulting & $40.00 \%$ & $46.67 \%$ & $66.67 \%$ & $48.39 \%$ \\
\hline Providing education & $0.00 \%$ & $33.33 \%$ & $0.00 \%$ & $16.13 \%$ \\
\hline $\begin{array}{l}\text { Bringing together different organizations } \\
\text { and individuals at the local level }\end{array}$ & $60.00 \%$ & $86.67 \%$ & $66.67 \%$ & $74.19 \%$ \\
\hline $\begin{array}{l}\text { Development of cooperation with entities } \\
\text { outside the municipality }\end{array}$ & $70.00 \%$ & $86.67 \%$ & $83.33 \%$ & $80.65 \%$ \\
\hline Collecting statistical data & $50.00 \%$ & $73.33 \%$ & $16.67 \%$ & $54.84 \%$ \\
\hline Research & $0.00 \%$ & $20.00 \%$ & $0.00 \%$ & $9.68 \%$ \\
\hline Marketing & $50.00 \%$ & $86.67 \%$ & $83.33 \%$ & $74.19 \%$ \\
\hline Infrastructure development & $70.00 \%$ & $80.00 \%$ & $50.00 \%$ & $70.97 \%$ \\
\hline Financial support & $20.00 \%$ & $33.33 \%$ & $33.33 \%$ & $29.03 \%$ \\
\hline $\begin{array}{l}\text { Active participation in the preparation of } \\
\text { legislation }\end{array}$ & $20.00 \%$ & $20.00 \%$ & $50.00 \%$ & $25.81 \%$ \\
\hline Operation of the tourist information centre & $10.00 \%$ & $13.33 \%$ & $0.00 \%$ & $9.68 \%$ \\
\hline Operation of tourism facilities & $20.00 \%$ & $20.00 \%$ & $16.67 \%$ & $19.35 \%$ \\
\hline Organization of cultural and social events & $70.00 \%$ & $66.67 \%$ & $33.33 \%$ & $61.29 \%$ \\
\hline Source: own en & & & \\
\hline
\end{tabular}

Source: own elaboration based on the results of primary research

intensity of use of tools by individual municipalities. Up to $90 \%$ of municipal representatives have confirmed that they use strategic documents and planning in the field of rural tourism as one of the tools for developing rural tourism. According to current legislation, the Municipal Development Program is the strategic document that municipalities should use to plan their strategic priorities in the field of tourism development. The survey showed that most municipalities have updated Municipal Development Program, mainly because of the interest in drawing financial support from the Structural Funds.

However, on the basis of interviews, we can say that many municipal representatives would not prepare this strategic document if it was not a prerequisite for obtaining financial support from public sources, quoting one of the municipal representatives: "Why would I need such a document, I do not need control". On the other hand, only about $67 \%$ of respondents from accommodation facilities and support organizations know that such documents exist and define priorities for rural tourism. From the municipalities in which we conducted interviews, only some of them had developed another, more specific strategic document, e.g. Rural Tourism Development Strategy. In the opinion of mayors, this is mainly due to the lack of emphasis on rural tourism development and they think that operators of accommodation facilities should be the main developers. Other tools that, according to the theoretical background, should positively influence the development of rural tourism are consulting and education in the field of rural tourism. However, only $40 \%$ of municipalities provide consulting in this area, particularly in utilising EU funds.
However, almost $67 \%$ of support organizations provide education, not only in the field of obtaining financial resources but also in marketing (e.g. web site creation, preparation of press releases). Representatives of local government and support organizations said they do not provide any education in rural tourism because of low demand and lack of trust from entrepreneurs, as confirmed by words of one of the accommodation facilities operators: "You cannot believe anything that you do not find out yourself". In the case of connecting different organizations and individuals active in rural tourism at local or on other levels, the respondents expressed their positive opinion, particularly regarding the civic associations (in this case, however, the municipality was not the initiator) or the creation of a local action group. However, with regard to the creation of local action groups it should be noted that, in some cases, mayors of municipalities were not initiators, rather the initiators were representatives of paying or development agencies. It follows that the awareness of some municipal representatives about the functioning of such partnerships is low. None of the respondents, whether from local self-government or supporting organizations, mentioned that they collect statistical data analysing capacity, the performance of businesses or traffic in these facilities in the municipality. However, $20 \%$ of accommodation facilities operators have confirmed, they are reporting the number of visitors through the collection of accommodation tax. Municipalities should then report annual summaries of the number of visitors to the relevant statistical office. Research in the field of rural tourism is not performed by 
any of the monitored municipalities or by support organizations, although $20 \%$ of operators said they think the municipality is using this tool. Representatives of municipalities agreed that research on the development of rural tourism, or generally tourism, should be carried out by research institutions, not only based on research orders by the central government but also based on the demand of self-governing regions or municipalities. $50 \%$ of municipalities support rural tourism through joint marketing activities - especially through municipal websites where municipalities publish a list and contact information of accommodation facilities located in the municipal territory (registered accommodation facilities). To other marketing tools, representatives of municipalities also included the marking of various tourist attractions in the municipality and the creation of promotional materials. Support organizations use similar marketing tools as municipalities, but because of their relatively higher marketing budget, they are often more innovative. One of the most used tools for the development of rural tourism by municipalities is construction, reconstruction, and maintenance of infrastructure associated with tourism, which representatives of municipalities consider to be a general development tool for the municipality (e.g. sewerage, water supply, road network, etc.). Only bicycle routes are specific to the tourism sector. A key issue in the development of rural tourism is also the financial support that most municipalities do not provide, which was justified by the mayors stating that it would be a direct support of private entities. Another factor is the limitation of budgets of rural municipalities through shared taxes, amount of which are derived from the number of inhabitants. In rural municipalities, these financial resources usually do not cover expenditures associated with the basic functioning of the municipality. Alternatively, they allocate funds to organize various social events attracting visitors to the municipality. It should be noted that only $20 \%$ of municipalities are actively involved in the preparation of legislation affecting the development of tourism, in particular through the ATMS (Association of Towns and Municipalities of Slovakia) or when the mayor of the municipality is also a representative of the higher territorial unit. Nearly $10 \%$ of all interviewed subjects agreed that tourism information center should be operated by a territorial or regional tourism organization that could promote not only the municipality in which the center would be located but the entire region, and thereby create a specific tourism product.

Comparing the importance (Fig. 1) of various rural tourism development tools between local selfgovernment and accommodation facilities operators, the greatest identified differences regarded opinions towards tools such as the provision of education, marketing of tourism, infrastructure development associated with tourism, financial support for the development of tourism and operation of the tourist information center. Representatives of individual municipalities perceive these tools several as times more important than operators of accommodation facilities. Both sides observed agree on the low importance of statistical data collection and active participation in the preparation of legislation affecting the development of rural tourism. We must mention that entities do not take the context of individual tools into consideration, as without the collection of statistical data it is not possible to properly prepare strategic documents and legislation that would reflect real needs.

The greatest differences in the perceived importance of individual tools for local self-government and support organizations can be observed (Fig. 2) in financial support for the development of rural tourism. Local government does not attach great importance to this tool (mainly due to a lack of financial resources), while the support organizations identified it as one of the most important. We can state that views on the importance of individual tools in local self-government and support organizations differ significantly, except tools such as statistical data collection and operation of tourism facilities (museums, galleries and other), the importance of which both groups of stakeholders judged as average. The figure shows that supporting organizations attach much more importance to almost all support tools and mechanisms than the representatives of local selfgovernment in the monitored territory. On the one hand, the difference in attitudes can be interpreted by different missions of these two types of stakeholders. While support organizations are established solely for the purpose of implementing support mechanisms in the tourism industry in the area concerned, the competences of local self-government are much wider and its mission is to ensure the overall development of the municipal territory. However, due to the key position of tourism industry in the region and its economic base, identified differences in attitudes (not only in comparison to support organizations but also to accommodation providers) may point to the underestimation of the importance of this industry and consequently to the underestimation of the support mechanisms which they have at disposal and which could contribute to a higher competitiveness of the local economy.

When comparing the importance of individual rural tourism development tools between accommodation facilities operators and support organizations (Figure 3), the highest consensus is reached. The biggest difference can be observed regarding the tool "Active participation in the preparation of legislation affecting rural tourism". We must state that the operators of accommodation facilities do not attach great importance to certain support tools, which is reflected in their apathetic attitude, best described by quoting one of the respondents: "what we don't do ourselves, we don't have, no one will give us anything for free and we cannot rely on anyone." Compared to accommodation providers, support organizations attach, in addition to the above-mentioned ones, relatively higher importance to the creation of strategic documents, partnerships, cooperation and financial support of the industry. According to the statements of individual accommodation providers, 
partnerships and networks operating in the field of tourism are only useful for certain businesses (especially the larger ones). On the other hand, in comparison with the opinion of support organizations, accommodation facilities would as a supportive tool welcome the operation of tourist information centers and other tourism facilities.

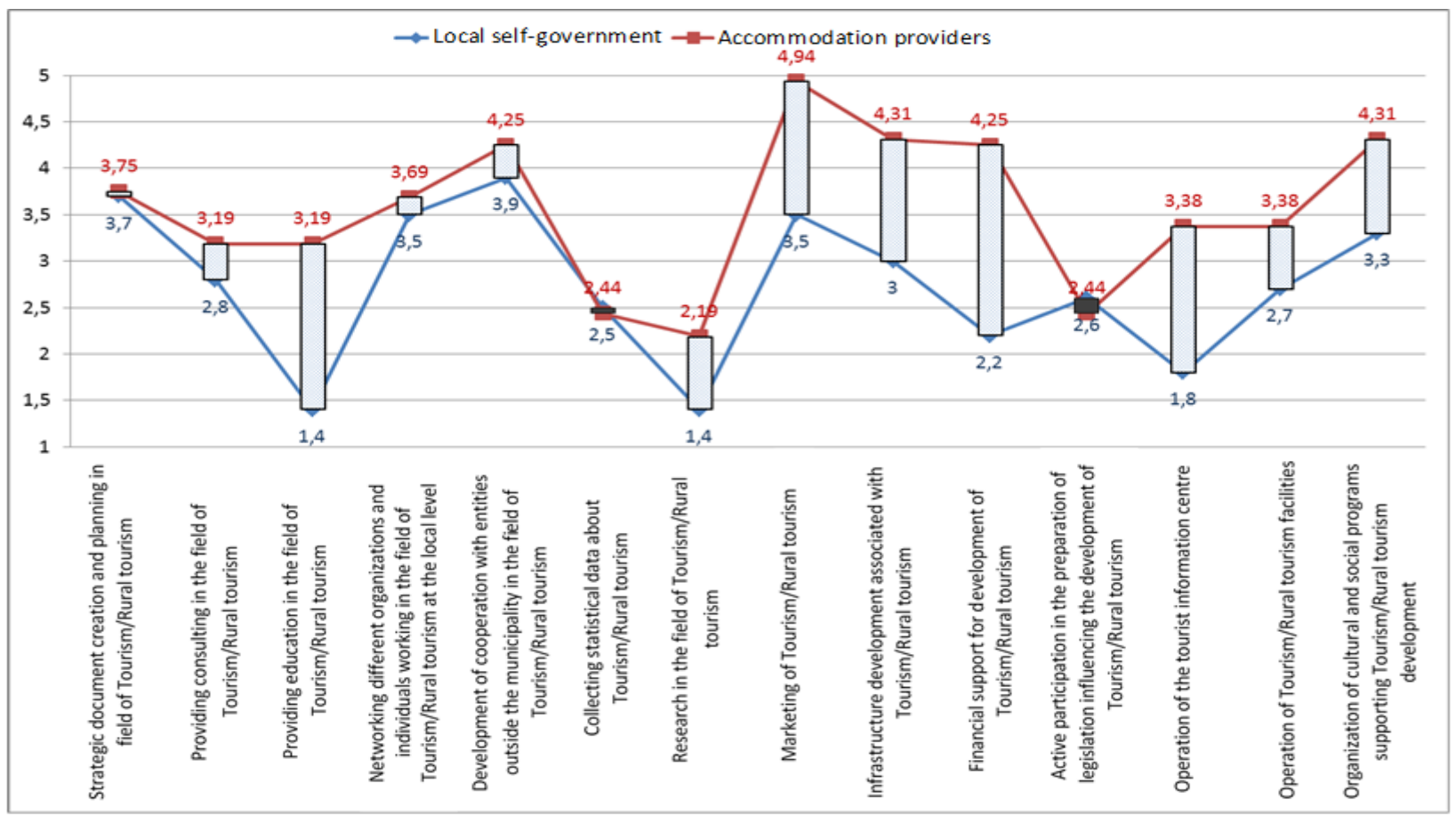

Figure 1 Comparison of the importance of selected rural tourism development tools according to local self-government representatives and accommodation providers

Source: own elaboration based on the results of primary research

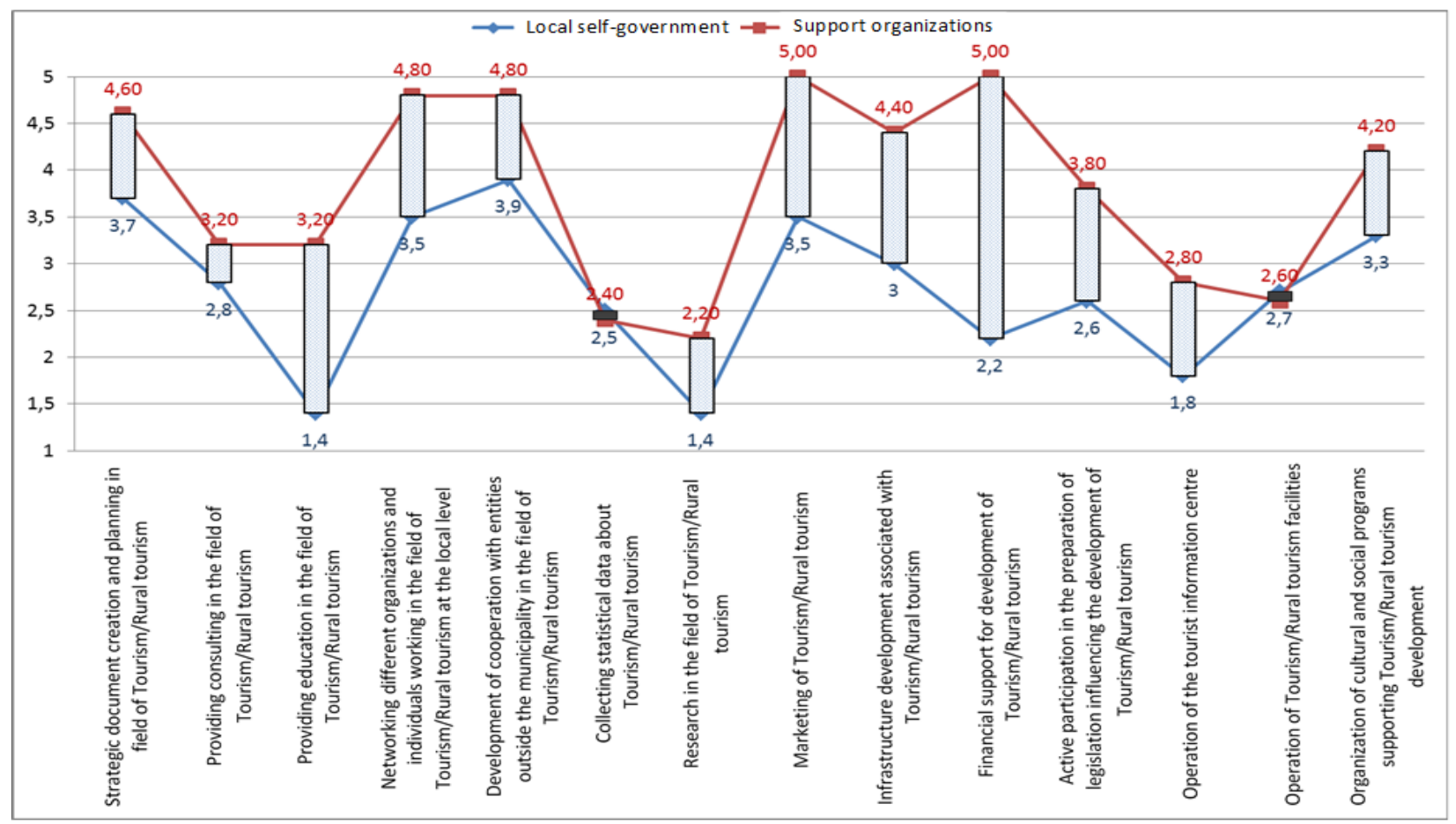

Figure 2. Comparison of the importance of selected rural tourism development tools according to local self-government representatives and support organisations (source: own elaboration based on the results of primary research). 


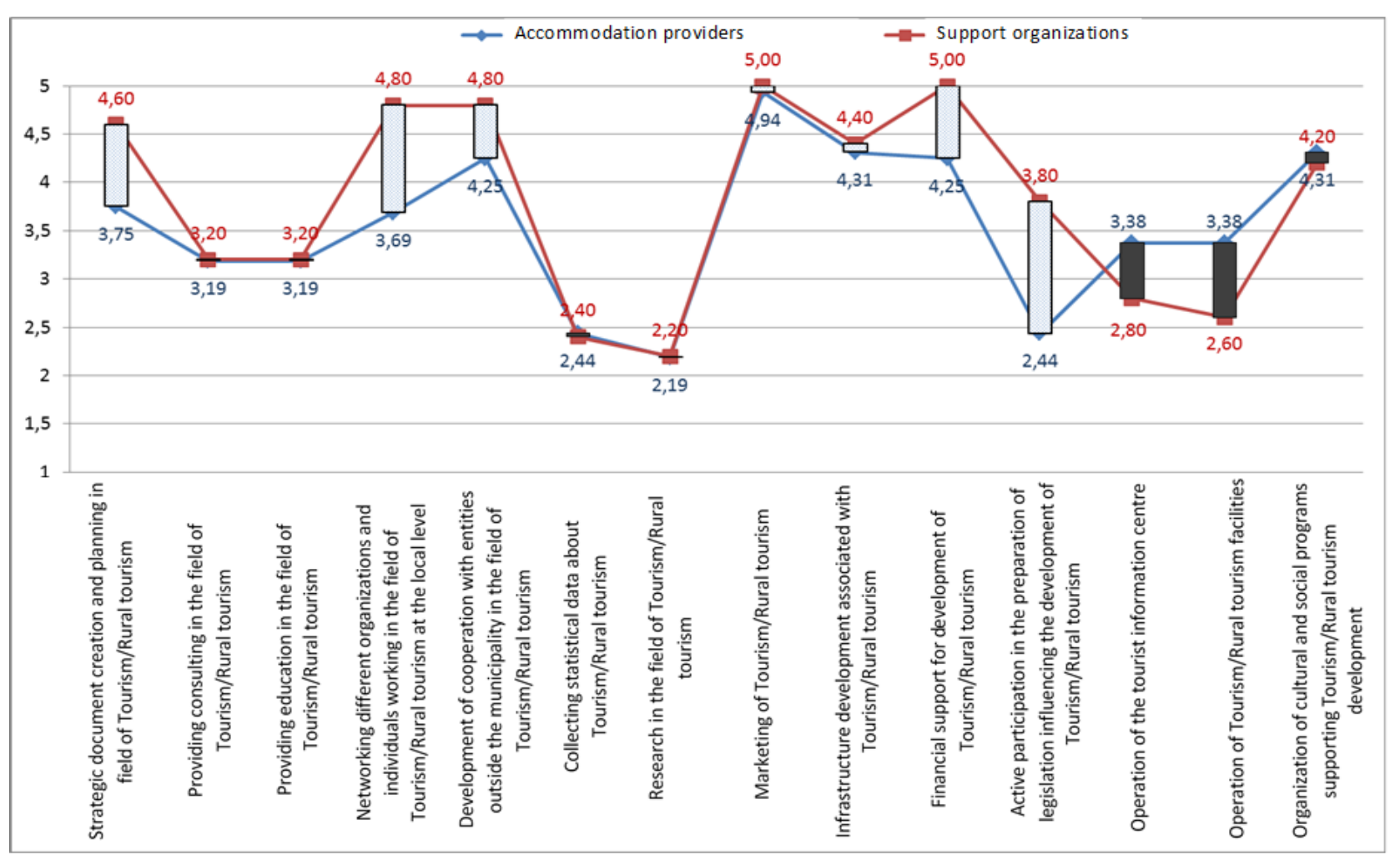

Figure 3 Comparison of the importance of selected rural tourism development tools according to accommodation providers and support organizations (source: own elaboration based on the results of primary research).

Table 3 Perception of barriers to the development of rural tourism by individual entities involved in the process of rural tourism development

\begin{tabular}{|c|c|c|c|c|}
\hline Barriers & $\begin{array}{l}\text { Local self- } \\
\text { government }\end{array}$ & $\begin{array}{c}\text { Accommodati } \\
\text { on providers }\end{array}$ & $\begin{array}{c}\text { Support } \\
\text { organizations }\end{array}$ & All entities \\
\hline Bureaucracy & $70.00 \%$ & $86.67 \%$ & $83.33 \%$ & $80.65 \%$ \\
\hline Corruption & $80.00 \%$ & $53.33 \%$ & $83.33 \%$ & $67.74 \%$ \\
\hline Passivity of citizens & $70.00 \%$ & $73.33 \%$ & $50.00 \%$ & $67.74 \%$ \\
\hline Passivity of entrepreneurs & $50.00 \%$ & $73.33 \%$ & $50.00 \%$ & $61.29 \%$ \\
\hline Unwillingness to cooperate & $50.00 \%$ & $66.67 \%$ & $50.00 \%$ & $58.06 \%$ \\
\hline Unavailability of financial resources & $70.00 \%$ & $80.00 \%$ & $50.00 \%$ & $70.97 \%$ \\
\hline $\begin{array}{l}\text { Insufficient collection of tax on } \\
\text { accommodation }\end{array}$ & $40.00 \%$ & $60.00 \%$ & $50.00 \%$ & $51.61 \%$ \\
\hline Bad condition/lack of technical infrastructure & $50.00 \%$ & $53.33 \%$ & $83.33 \%$ & $58.06 \%$ \\
\hline Bad condition/lack of social infrastructure & $60.00 \%$ & $46.67 \%$ & $66.67 \%$ & $54.84 \%$ \\
\hline Lack of accommodation facilities & $40.00 \%$ & $6.67 \%$ & $16.67 \%$ & $19.35 \%$ \\
\hline Lack of catering facilities & $60.00 \%$ & $60.00 \%$ & $16.67 \%$ & $51.61 \%$ \\
\hline Weak marketing of the municipality & $40.00 \%$ & $66.67 \%$ & $50.00 \%$ & $54.84 \%$ \\
\hline $\begin{array}{l}\text { Weak marketing of activities promoting } \\
\text { tourism development }\end{array}$ & $50.00 \%$ & $80.00 \%$ & $83.33 \%$ & $70.97 \%$ \\
\hline Lack of information tools & $50.00 \%$ & $53.33 \%$ & $16.67 \%$ & $45.16 \%$ \\
\hline Insufficient/no education activities & $40.00 \%$ & $66.67 \%$ & $50.00 \%$ & $54.84 \%$ \\
\hline $\begin{array}{l}\text { Insufficient/no consulting services in the field } \\
\text { of tourism }\end{array}$ & $40.00 \%$ & $60.00 \%$ & $33.33 \%$ & $48.39 \%$ \\
\hline
\end{tabular}

Source: own elaboration based on the results of primary research 
By using structured interviews among respondents, we analyse how they perceive barriers (Table 3) to the development of rural tourism. As the biggest barrier to development, respondents identified bureaucracy, particularly in obtaining financial resources. Up to $68 \%$ of all respondents also identified corruption as an obstacle to the development of rural tourism. However, they refused to specify the context regarding this problem. The passivity of citizens and businesses to public affairs in monitored municipalities was confirmed not only by municipality representatives but also by operators of accommodation facilities, who stated that they do not have time and capacities to actively participate in public-service events. This barrier could be removed if both sides realize the mutual benefits of cooperation. $70 \%$ of municipal representatives said that they consider the unavailability of financial resources as a barrier to development, but the majority later corrected this statement to the difficulty of obtaining these funds through various Structural Funds or other grant schemes. As for the supporting organizations, only half of them sees the unavailability of financial resources as a barrier to development, which is confirmed by the statement of one of the respondents: "there are a lot of financial opportunities, it is only necessary to know how to obtain them".

Half of all respondents highlighted existing problems with collecting tax on accommodation, however, the nature of these problems varies depending on the group of entities. While municipalities mention problems with the control of registered and unregistered accommodation facilities and the number of their visitors, several accommodation facilities operators have stated that the collected funds should be primarily reinvested in the development of tourism in the territory concerned, which according to them is not happening right now. A minor barrier is the lack of accommodation facilities, but more than half of respondents (mostly municipalities and private sector entities) report the number of catering facilities as inadequate. Approximately half of respondents are not satisfied with the level of technical infrastructure, but also with the level of educational, consulting and information activities. Accommodation providers point out the need for more innovative promotion tools from local self-government and support organizations, not just in form of web pages and newsletters. This attitude was also reflected in their considerably more critical evaluation of marketing activities.

We have also examined the importance of individual barriers for different entities. We can state that local selfgovernment representatives have evaluated individual barriers to the development of rural tourism much less critically than operators of accommodation facilities (Fig. 4). The greatest barrier to operators of accommodation facilities are marketing activities of the municipality, where their facilities are located, or in general, activities supporting the development of tourism. Within these two selected development barriers, we can observe a big difference between the importance of barriers to local self-government, whose leaders do not think that their use of marketing tools is insufficient and accommodation providers' opinion. The largest consistency of responses has occurred within the following barriers: citizens' passivity and corruption.

Differences similar to the previous comparison have also occurred between local self-government and support organizations (Fig. 5). Their views are diametrically different, especially in terms of the lack of, or poor condition of technical and social infrastructure and marketing activities as barriers to the development of rural tourism. The smallest variability of responses was in case of the availability of financial resources as a development barrier, where the entities consider this barrier as quite serious.

The greatest consensus of answers between accommodation facilities operators and support organizations (Fig. 6) was in case of comparing the importance of individual barriers to the development of rural tourism. However, their views differ in the lack of catering facilities and insufficient collection of tax on accommodation which, as we have already mentioned, is also linked to the problem of unregistered accommodation facilities. Both groups of stakeholders agreed that lack of accommodation facilities is not a barrier to the development of rural tourism.

\section{Conclusion}

The purpose of rural tourism support predominantly lies in addressing the problems of rural municipalities and rural regions, arising from changes in the position of agriculture in the rural area, which is accompanied by a decline in employment in this sector. In the context of other problems of rural municipalities and regions, such as insufficient infrastructure, fragmented settlement structure and related low potential of labor and sales market, this change causes depopulation of a large part of rural municipalities and weakening of their economic base by increasing dependence on urban economy. In this context, support for rural tourism seeks to find alternative sources of income and employment.

Based on structured interviews, we can identify the individual needs of entities operating at the local and regional level. Business entities operating in the field of rural tourism identified several needs that affect the development of their businesses and, in general, rural tourism industry. They highlight, in particular, the development of cooperation with entities operating not only within the municipality in which they are located but also with entities from outside which would provide better information and consulting services availability. As the most important need, private sector entities have identified the development of marketing activities, which affects primarily the demand side of the market. Based on this, we would propose to adjust the focus of tourism support policies from supply-oriented to demandoriented, which would also help increase the accommodation capacity utilization. 
Respondents identified bureaucracy as the greatest barrier to the development of rural tourism, in particular the complexity and volume of procedural steps required of the private sector entities in Slovakia. On the other hand, respondents do not perceive the lack of accommodation facilities as a barrier to rural tourism development, which again highlights the problem of supply-oriented policy and the need to focus on increasing the capacity utilization of these facilities by supporting demand. The most important tools for supporting rural tourism are those that support the cooperation of individual entities, through which the flow of information, consulting, education and especially the creation of the comprehensive regional product is ensured.

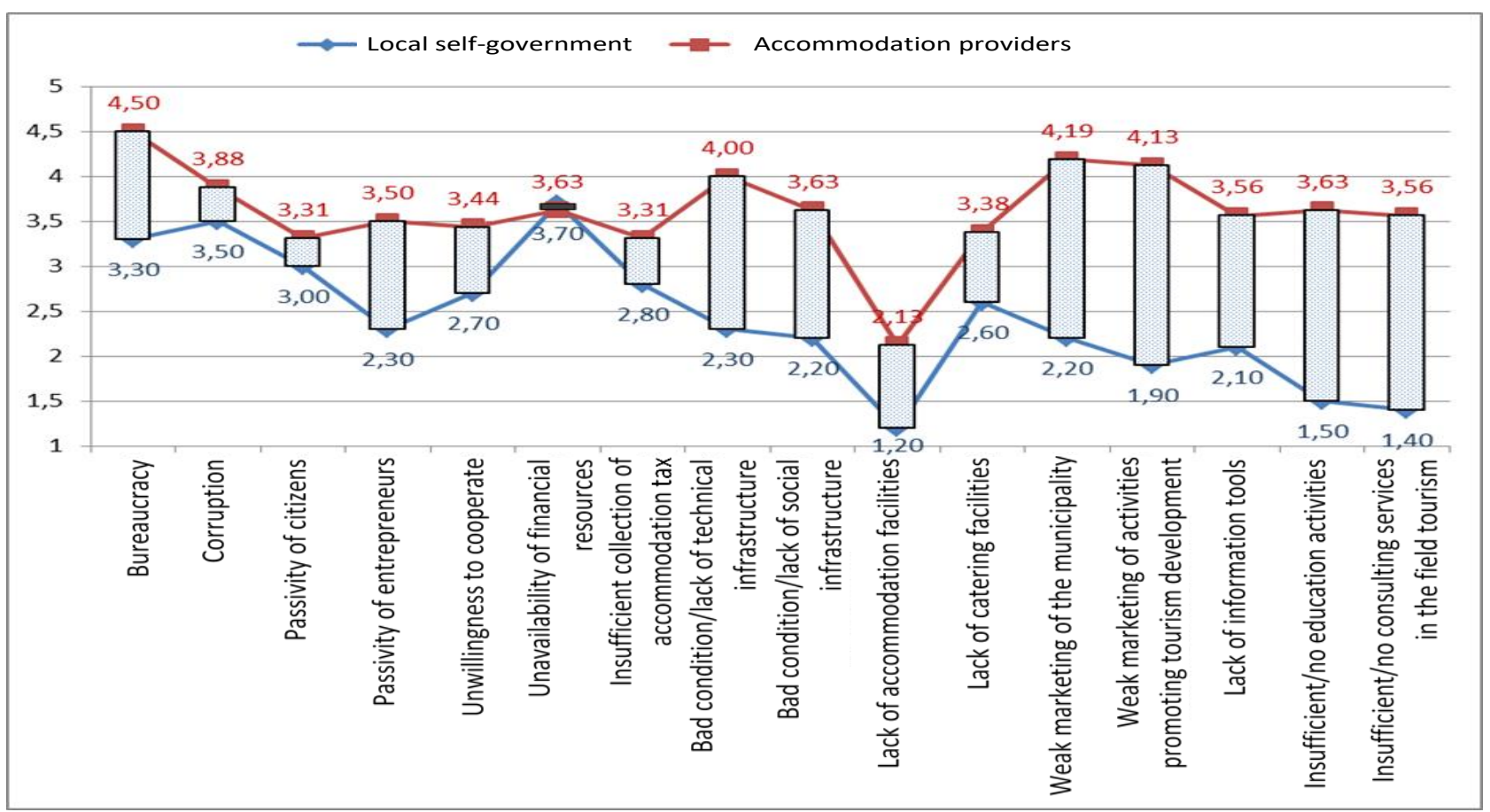

Figure 4 Comparison of the importance of selected rural tourism development barriers to local self-government representatives and accommodation providers (source: own elaboration based on the results of primary research).

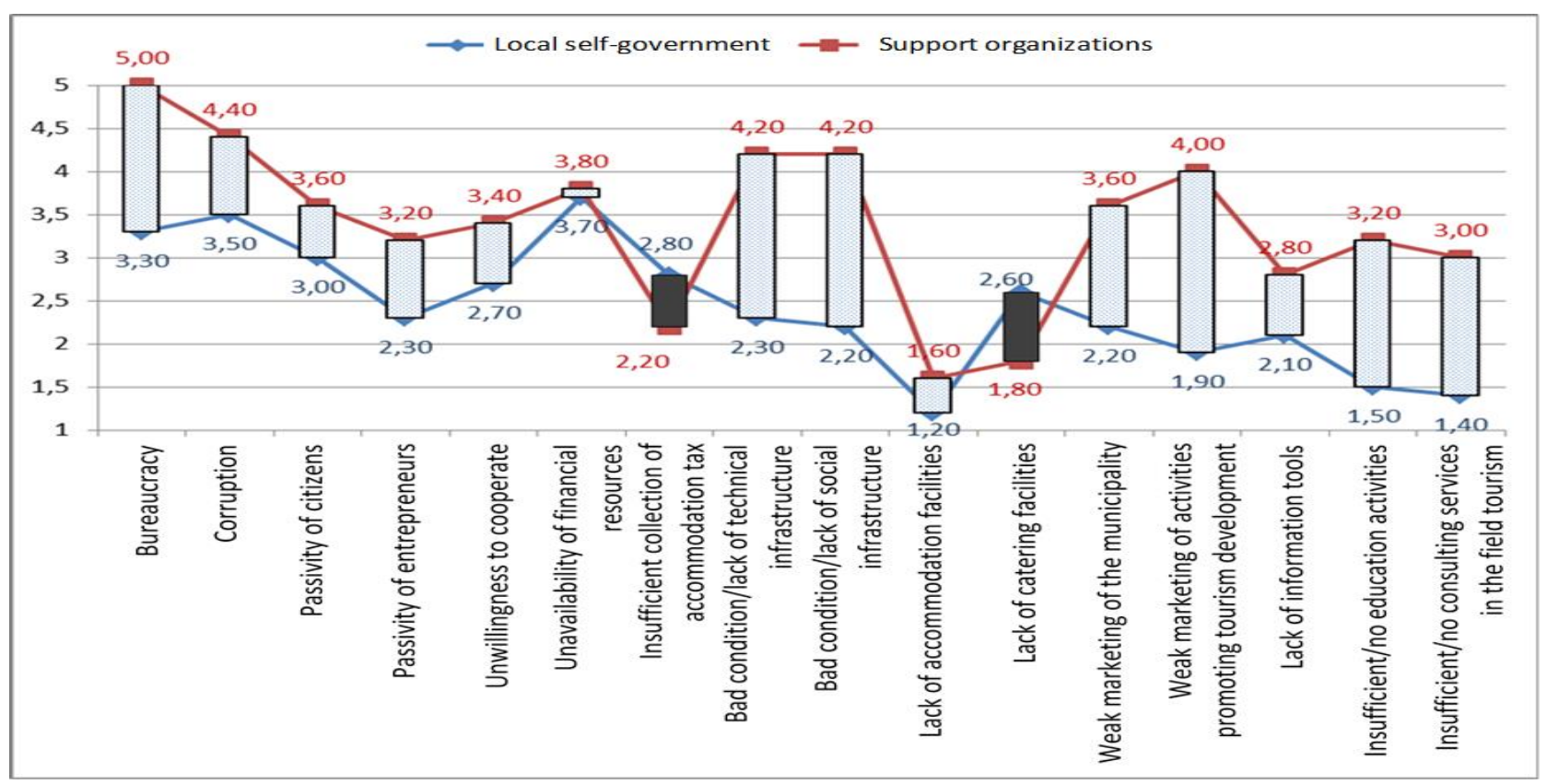

Figure 5 Comparison of the importance of selected rural tourism development barriers to local self-government representatives and support organizations (source: own elaboration based on the results of primary research). 


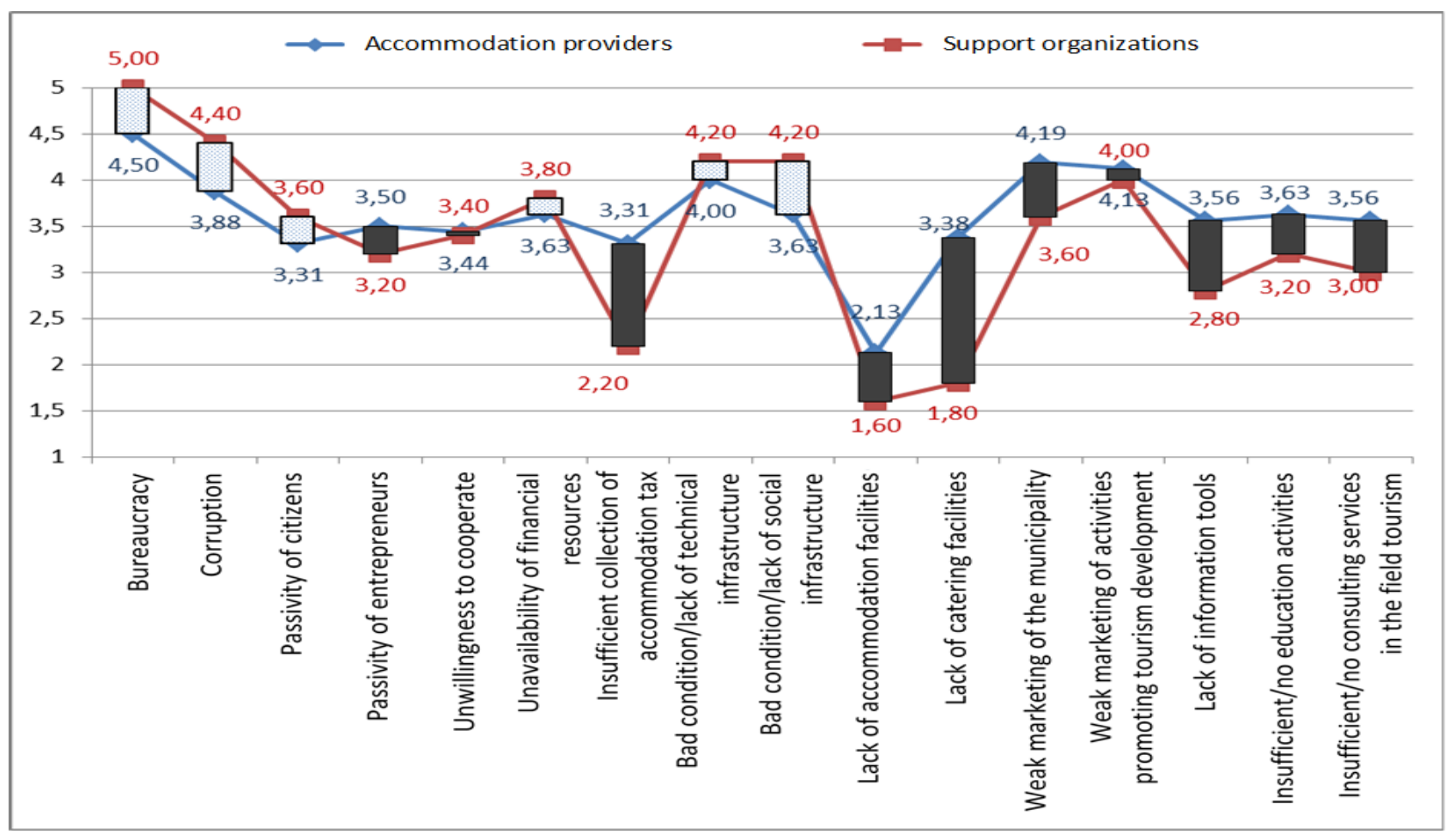

Figure 6 Comparison of the importance of selected rural tourism development barriers to accommodation providers and support organizations (source: own elaboration based on the results of primary research).

\section{Acknowledgements}

This paper is an output of Erasmus+ KA2 Strategic partnership project SUMCULA (Sustainable Management of Cultural Landscapes - 2017-1-SE01KA203-034570), and Cultural and Educational Grant Agency KEGA project New Approaches in Teaching Local Economic and Social Development (047SPU4/2018).

\section{References}

Bessière, J. 2008. Local Development and Heritage: Traditional Food and Cuisine as Tourist Attractions in Rural Areas. In Sociologia Ruralis 38(1): 21-34.

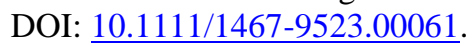

Binek, J. et al. 2007. Rural space and its revitalisation (Venkovský prostor a jeho oživení). Brno : Georgetown, 140 p. ISBN 80-251-19-5.

Available at:

http://www.garep.cz/wp-

content/uploads/2013/03/Venkovsky_prostor.pdf.

Binek, J. et al. 2009. Synergies in rural areas - Actors and tools in rural development (Synergie ve venkovském prostoru - Aktéri a nástroje rozvoje venkova). Brno : Garep, s.r.o. ISBN 978-80-904308-0-8.

Galvasová, I. et al. 2008a. Tourism Industry (Průmysl cestovního ruchu). Brno : GAREP. 2008. 262 p. ISBN 978-80-87147-06-1.
Galvasová, I. et al. 2008b. Rural development tools and their application. Study from the A803 activity of the QH82249 project Synergy approach to rural development (Nástroje rozvoje venkova a jejich uplatňování. Štúdia z riešenej aktivity A803 projektu QH82249 Synergie v prŕstupu k rozvoji venkova). Brno : GAREP. 2008.

García, A. J., Gómez, M., Molina, A. 2012. A destination-branding model: An empirical analysis based on stakeholders. In Tourism Management, 33(3): 646661.

DOI: $\underline{10.1016 / \text { j.tourman.2011.07.006. }}$.

Gúčik, M. et al. 2010. Tourism Management (Manažment cestovného ruchu). Banská Bystrica : Univerzita Mateja Bela, Ekonomická fakulta, Revised: 2017, 198 p. ISBN 978-80-89090-67-9.

Gúčik, M. et al. 2012. Management of tourism destination (Manažment ciel'ového miesta cestovného ruchu). Banská Bystrica : Univerzita Mateja Bela, Ekonomická fakulta, 220 p. ISBN 978-80-8141-025-3.

Himmelman, A. T. 1996. On the Theory and Practice of Transformational Collaboration: From Social Service to Social Justice. In Creating Collaborative Advantage. pp. 19 - 43. ISBN-0-8039-7499-1.

Hudec, O. et al. 2009. Forms of regional and local development (Podoby regionálneho a miestneho rozvoja). Košice : Technická Univerzita. ISBN 978-805530117-4. 
Irshad, H. 2010. Rural Tourism - an overview. Rural Development Division, Government of Alberta, Canada. Available at: http://www1.agric.gov.ab.ca/\$Department/deptdocs.nsf/a 11/csi13476/\$FILE/Rural-Tourism.pdf.

Jamal, T. B., Getz, D. 1999. Community roundtables for tourism-related conflicts: The dialectics of consensus and process structures. In Journal of Sustainable Tourism 7(3-4): 290-313.

DOI: $\underline{10.1080 / 09669589908667341}$.

Jarábková, J. 2010. Countryside - Untapped potential for rural tourism (Vidiek - nevyužitý potenciál pre vidiecky cestovný ruch). Slovenská pol'nohospodárska univerzita v Nitre. ISBN 978-80-552-0364-5.

Jovanovic, S., Ilic, I. 2016. Infrastructure as an important determinant of tourism development in the countries of Southeast Europe. In Ecoforum 5(8): 288-294.

Available at: www.ecoforumjournal.ro/index.php/eco/article/downloa d/329/216.

Kučerová, J. 1999. Sustainable development of tourism (Trvalo udržatel'ný rozvoj cestovného ruchu). Banská Bystrica : Univerzita Mateja Bela, Ekonomická fakulta, 1999. 83 p. ISBN 80-8055-307-6.

Kurpaš, M., Zima, R. 2012. Traditional Architecture and Competitiveness in Hotel Management (Tradičná architektúra a konkurencieschopnost' $\mathrm{v}$ hotelierstve). In Konkurenceschopnost v cestovním ruchu, gastronomii a hotelnictví : sborník příspěvků z páté mezinárodní konference, Brno $3^{\text {rd }}$ May Brno : Vysoká škola obchodní a hotelová, pp. 146-154. ISBN 978-80-87300-18-3.

Mach, F. et al. 1993. Business guide in rural tourism and agro-tourism (Sprievodca podnikatel'a vo vidieckom turizme a agroturizme). Bratislava : RÉKA. 166 p. ISBN 80-88731-03-8.

Maier, G., Tödtling, F. 1998. Regional and Urban Economy 2 - Regional Development and Regional Policy (Regionálna a urbanistická ekonomika 2 Regionálny rozvoj a regionálna politika). Bratislava : Elita. ISBN 80-8044-049-2.

Maráková, V., Gajdošík, T. 2013. Theory of stakeholder cooperation at the tourism destination (Teórie kooperácie zainteresovaných subjektov $\mathrm{v}$ ciel'ovom mieste cestovného ruchu). In Folia Turistica 3 : zborník vedeckých prác. Banská Bystrica : Univerzita Mateja Bela, Ekonomická fakulta, pp. 102-111. ISBN 978-808141-040-6.

Medvecká, M. 2006. Restoration of cultural heritage - a prerequisite for attractive tourist offer in rural areas. Cofinancing options (Obnova kultúrneho dedičstva - predpoklad atraktívnej ponuky cestovného ruchu vo vidieckych oblastiach). Možnosti spolufinancovania.

Available

at: http://www.agroturist.sk/konferencia/files/ObnovaPredn aska.rtf.

Michalík, B. in Lenovský, L. et al. 2014. The contexts of cultural heritage and tourism in Slovakia: textbooks on selected problems (Kontexty kultúrneho dedičstva a turizmu na Slovensku: učebné texty $\mathrm{k}$ vybraným problémom). Nitra: UKF, 124 p. ISBN 978-80-5580494-1.

Michálková, A. 2010. Regional networks in tourism (Regionálne siete $\mathrm{v}$ cestovnom ruchu). Bratislava : Ekonomická univerzita v Bratislave. 130 p. ISBN 97880-557-0059-5.

Ministry of Transport and Construction. 2013. Tourism Development Strategy of the Slovak Republic up to 2020.

Nitra Self-Governing Region. 2016. Certification of accommodation facilities in rural areas (Certifikácia ubytovacích zariadení na vidieku).

Available

at:

http://ubytovanienavidieku.sk/index.php/zaujimavostinitrianskeho-regionu-2/vseobecne-informacie.

Paimin, N.F.V, Modilih, S, Mogindol, S. H., Johnny, C., Thamburaj, J. A. 2014. Community Participation and Barriers in Rural Tourism: A Case Study in Kiulu, Sabah In SHS Web of Conferences 12(1): 1-7. DOI: $10.1051 /$ shsconf/20141201003.

Palenčíková, Z. 2010. The current state of cooperation of the public and private sector in tourism in the Slovak Republic (Súčasný stav spolupráce verejného a súkromného sektora $\mathrm{v}$ cestovnom ruchu $\mathrm{v}$ Slovenskej republike). In Ekonomická revue cestovného ruchu 43(1): 67-77. ISBN 0139-8660.

Petrychenko, P., Melnyk, I. 2013. Barriers and possible ways of developing rural tourism in Odessa region of Ukraine, Romanian rural tourism in the context of sustainable development. Tehnopress, Iasi, pp. 84-88.

Available

at:

http://dspace.oneu.edu.ua/jspui/handle/123456789/4573.

Plzáková, L., Studnička, P. 2013. Approaches to Managing Destinations in the Czech Republic - Current Situation. In Ekonomická revue cestovného ruchu 46(4): 204-214. ISSN 0139-8660.

Slovak Republic Act no. 91/2010 Coll. on the support of tourism.

Available at: http://www.epi.sk/zz/2010-91. 
Toušek, V., Kunc, J., Vystoupil, J. et al. 2008. Economic and social geography (Ekonomická a sociální geografie). Plzeň: Aleš Čeněk, 411 p. ISBN 978-80-7380-114-4.

UNWTO. 2007. A practical guide to tourism destination management. Madrid: World Tourism Organization. 150 p. ISBN 978-92-844-1243-3.

Vaisová, L. 2008. Rural Tourism - Comparative Study of the Pilsen Region and Bretagne: Diploma Thesis (Venkovský cestovní ruch - srovnávací studie Plzeňského kraje a Bretagne: diplomová práca). Brno: Masarykova Univerzita.
Výrostová, E. 2010. Regional economy and development (Regionálna ekonomika a rozvoj). Bratislava: IURA EDITION, 352 p., ISBN 978-80-8078-361-7.

Wang, Y., Krakover, S. 2008. Destination marketing: competition, cooperation or coopetition? In International Journal of Contemporary Hospitality Management 20(2): 126-141.

DOI: $\underline{10.1108 / 09596110810852122 .}$

Wokoun, R., Mates, P. 2006. Regional Policy Management and Public Administration Reform (Management regionální politiky a reforma veřejné správy), Praha : Linde. ISBN 80-7201-608-3. 